\title{
膵管非拡張慢性膵炎に対する膵神経叢全切除術
}

\begin{tabular}{|c|c|c|c|c|c|c|c|}
\hline & & & 熊本大 & 1 外科 & & & \\
\hline 平岡 & 武久 & 渡辺 & 栄二 & 加藤 & 哲夫 & 林田 & 信夫 \\
\hline 山崎 & 謙治 & 水谷 & 純一 & 金光苟 & 女一郎 & 宮内 & 好正 \\
\hline & & & 多良 & 立病院 & & & \\
\hline & & 木 & 本 & 明 & 博 & & \\
\hline & & & 菊池 & 病院 & & & \\
\hline & & 信 & 岡 & 博 & 済 & & \\
\hline
\end{tabular}

\section{COMPLETE DENERVATION OF THE PANCREAS FOR CHRONIC PANCREATITIS WITHOUT PANCREATIC DUCT DILATION}

\author{
Takehisa HIRAOKA, Eiji WATANABE, Tetsuo KATOH, \\ Nobuo HAYASHIDA, Junichi MIZUTANI, Kenji YAMASAKI, \\ Keiichiro KANEMITSU Akihiro KIMOTO* Hironari NOBUOKA** \\ and Yoshimasa MIYAUCHI
}

First Department of Surgery, Kumamoto University Medical School

*Department of Surgery, Taragi Public Hospital

**Department of Surgery, Kikuchi Central Hospital

索引用語：慢性膵炎, 膵管非拡張慢性膵炎, 膵神経叢全切除術

はじめに

慢性膵炎に対し，いろいろな手術術式が主に膵管拡 張の程度によって改良，工夫されてきた，膵管拡張例 においては, 膵管ドレナージ手術が行われ， ほぼ良好 な成績が得られている.しかし，膵管非拉張例に対し ては，いまだ確立した術式はない，われわれは疼痛の コントロールと膵機能温存を目的とした膵神経叢全切 除術を行い良好な結果を得, 本術式は膵管非执張慢性 膵炎に対する新術式となりらると考えられ"，ここに 報告する。

\section{手術方法}

膵神経叢全切除術式は膵以外への影響を最小限にす るため, 左右の腹腔神経節から膵への節後線維を図 1 の点線が示すごとく, 膵に接して完全に切離し, 膵を 頭部より脾門部まで後腹膜腔より完全に遊離するもの である、吉岡ら゙によって報告された膵頭神経叢第 I 部の切除, または第 I 部と第II 部の切除の膵の部分的 神経丵切除と異なり, 完全に神経丵切除を行うもので

$<1987$ 年 4 月 15 日受理 > 別刷請求先：平岡 武久 T860 熊本市本荘 1-1-1 熊本大学医学部第 1 外科
図1 膵神経叢全切除術の模式図. 点線は切除線を示 †.

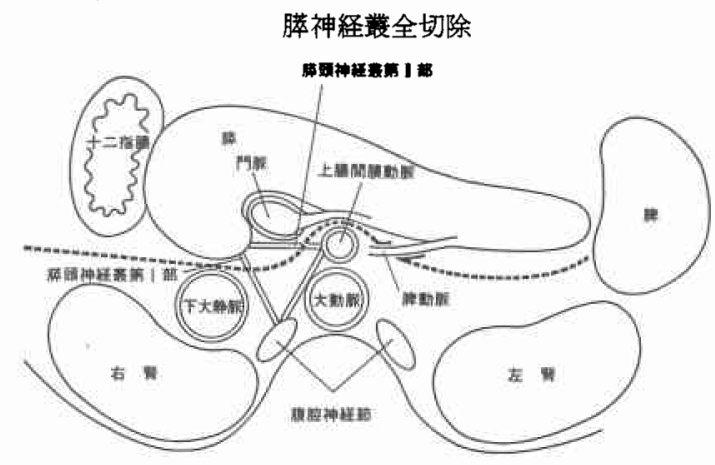

ある。

開腹し, すず Kocherの十二指腸授動術を, 上腸間膜 動脈根部が触知されるところまで行う。ついで総肝動 脈を膵頭上縁より露出し，胃十二指腸動脈，固有肝動 脈の一部が露出分離されるよらにする。ささらに膵上縁 で脾動脈を剝離し，脾動脈分岐部から膵付着部よりさ らに左側へ2 $3 \mathrm{~cm}$ の脺後面まで, 脾動脈周囲の神経 叢を切離する。これらの操作の後, 中結腸動脈を指標 
として上腸間膜動脈の右縁を剥離し，上腸間膜動脈と 上腸間膜静脈の間で，膵頭神経叢第 II 部を膵に接して caudal より cranial に切離していく。この際，下膵十 二指腸動脈の 1 本または 2 本を神経叢と一緒に切離す る.さらに上腸間膜静脈および門脈本幹後面で, 膵に 接して膵頭神経叢第 I 部を肝十二指腸間膜後面に向 かって切離していくこの方が，その逆の操作よりも 神経叢をより膵に接して切離することが容易にでき る. その後, 膵体尾部を脾静脈, 下腸間膜静脈後方で 左側へ脾門部をで剥離する，膵を後腹膜腔より完全に 遊離し，本手術を終了する。

\section{症 例}

本術式をらけた症例は 3 例である。

症例 1 は44歳の男性で，持続する心墖部痛を主訴と 乙, 日本酒 1 日 $3 \sim 5$ 合の約 20 年間の领酒歷がある. 現病歴は昭和 55 年 6 月に痛みが出現し, 次第に増強し 昭和 58 年 5 月以後は月に $1 \sim 2$ 回の激痛のため, ペン タゾシンの投与で，その耽溺状態に陥っていた。

膵機能は75g 経口糖負荷試験で糖尿病型を呈し, サ スタージンを負荷した pancreatic function diagnostant test（以下サスタージュン負荷 PFD test と略）では50.7\%であった. endoscopic retrograde pancreatography (以下 ERP と略) では膵管の抎張は 認めず, computed tomography（以下 CT と略）では 膵石像は認めなかった。

本手術を昭和58年 7 月 26 日に行った。膵は外見上小 葉構造は認められず，膵全体が硬化していた，総胆管 の拡張は認めなかった。術後 3 年 5 力月の現在, 疼痛 は全く消失し，下痢などの合併症はない，1 日20単位 のレンテインスリンの投与を受け，一時術前の仕事に 復帰したが，入院を繰り返している。術後 1 年 2 月の CT では，膵体部に術前認めなかった膵石像を認めた。 術後の膵機能は, $75 \mathrm{~g}$ 経口糖負荷試験験で, 図 2 のごと く術後 2 年 7 カ月の時点で術前に比べて軽度の悪化を 認め, サスタージュン負荷 PED test は術前の50.7\% から術後 1 カ月の時点で $84.7 \%$ になった。

症例 2 は37歳の男性で，心䆚部痛，背部痛を主訴と して, 焼酎 1 日 4 合, 15年間の飲酒歷を有し, 現病歴 は昭和 55 年末に疼痛が出現し, 以後次第に増強し, 昭 和59年 7 月以後から毎日ペンタン゙シンの投与を受ける よらになった。膵機能は $75 \mathrm{~g}$ 経口糖負荷試験で糖尿病 型を呈し，サスタージュン負荷 PFD test では $34.2 \%$, pancreozymin secretin test では, 重炭酸塩濃度の低 下と液量減少の 2 因低下を示した. ERP では膵管の拡 張はなく，CTでは膵石像を認めた。

本術式を昭和 59 年 10 月 3 日に行った。膵は全体に硬
因 2 症例 1 の耐糖能の推移 $75 \mathrm{~g}$ 一経口糖負荷試験 症例：44歳, 今

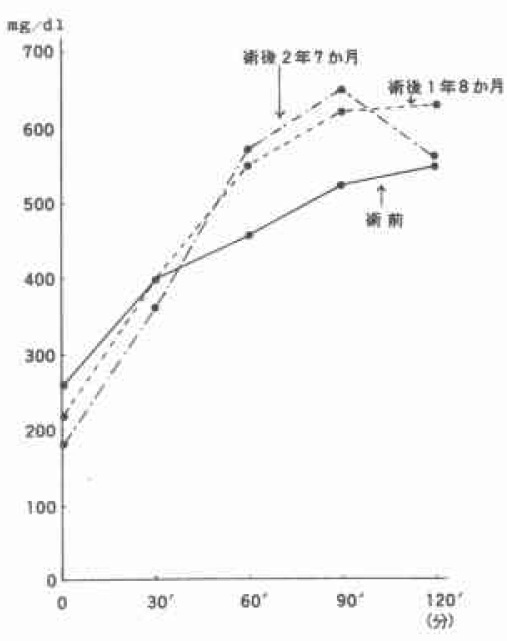

く,体尾部は腫大していた, 総胆管の拡張は認めなかっ た. 術後 2 年 3 力月の現在, 疼痛は消失し, 下琍など の合併症は認めず仕事に従事している。しかし，本例 においては, 術後 1 カ月と 2.6 月の 2 度にわたって, 2 3 日持続した一過性の血清アミラーゼ值の上昇を 伴う軽い左季肋部痛を認めた。術後膵機能は $75 \mathrm{~g}$ 経口 糖負荷試験は図 3 のごとく術後 6 力月の時点で術前と 比べ軽度の改善を認め, サスタージュン負荷, PFD test では術前の $34.2 \%$ から術後 1 カ月には $55.8 \%$ に なっていた，CTでは膵石像は術前後において著变を 認めていない。

症例 3 は44歳の男性で, 心窝部痛, 背部痛を主訴と 乙，焼酎 1 日 $2 \sim 3$ 合， 24 年間の领酒歴を有し，現病 歴は昭和53年某医にて急性腹症で， T 字管挿入，膵周 用腹腔内ドレナージ手術を受け，その後しばしば心窝 部痛を繰り返しては入院加療を受けていた。60年 3 月 には疼痛のためペンタゾシンの投与を連日必要とする ようになった，膵機能は $75 \mathrm{~g}$ 経口糖負荷試験で糖尿病 型を呈し, PFD test では74.2\%であった. ERPでは脺 管径は $5 \mathrm{~mm}$ で膵管内に膵石を認め, CT でも膵石像を 認めた。

本術式を昭和 60 年 5 月 21 日行った。膵は全体に硬く, 腫大していた。術後 3 週間，下䦌が持続したが，術後 1 年 7 力月の現在疼痛は消失し, 仕事に従事している. 術後膵機能は $75 \mathrm{~g}$ 経口糖負荷試験は術後 10 力月の時点 で，図 4 のごとく軽度の悪化を認め, PFD test では術 前の $74.2 \%$ か，術後 1 カ月には $57.8 \%$ となり，術前 に比べ低値を示した。 
図 3 症例 2 の耐糖能の推移 $75 \mathrm{~g}$ 一経口糖負荷試験 症例：37歳, 今

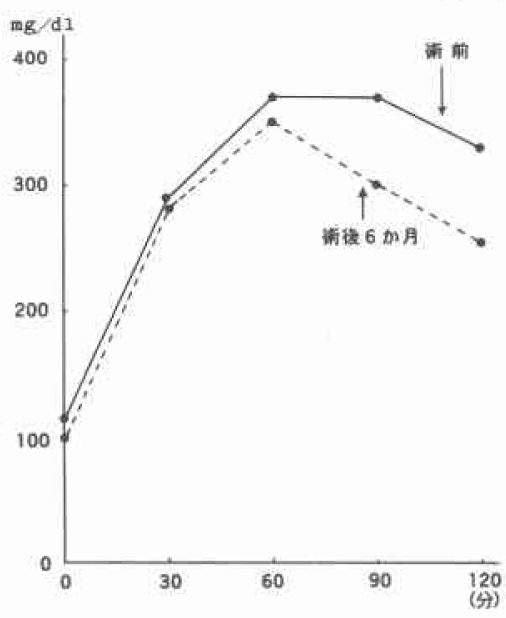

図 4 症例 3 の耐糖能の推移 $75 \mathrm{~g}$ 一経口糖負荷試験 症例：44歳, 令

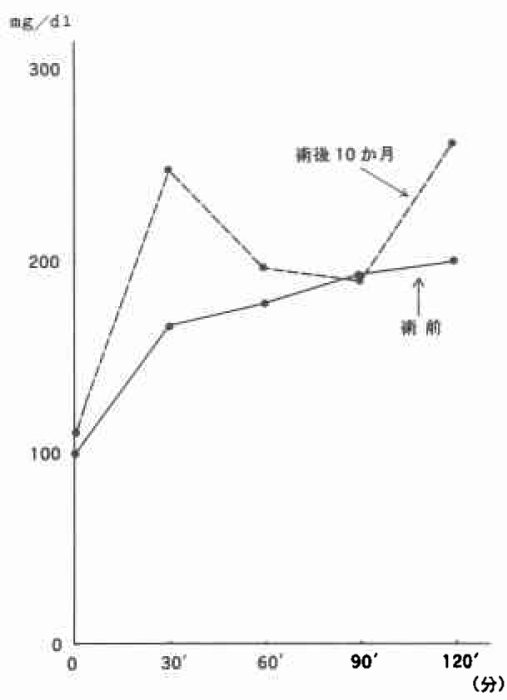

考察

膵管非拡張慢性膵炎は厳密には慢性膵炎があるにも かかわらず，主膵管に払張がなく，正常範囲内にある すのと定義されると思われる。しかし外科的治療の面 から，払張，非拡張の程度を検討すると，慢性膵炎の 外科手術術式が主に膵管の拡張閉塞いかんによって， その手術術式が種々考案されていることからすれば, 膵管ドレナージ手術が可能か否かの主膵管径が $6 \mathrm{~mm}$ 未満のbのを, 便宜上, 膵管非拡張慢性膵资として取
り报ってよいように思われる。しかし，これにる膵病 変が限局性か，膵全体のびまん性かに分けられると思 $5^{3)}$. 外科治療上限局性病変例に対しては, その限局性 病変に対処することによって良好な結果が得られ，特 に問題点はないと思われる。しかし，びまん性病変例 に打いては，現在特に確立した術式はなく，このよう な症例に対する手術術式の選択には問題がある。膵管 径6mm 未満の症例には脺管空腸側側吻合術は適応し がたく、われわれは膵管径 $5.5 \mathrm{~mm}$ の症例に膵管空腸側 側吻合術を行ったが，術後 4 年 8 カ月の萃管造影で吻 合部は閉塞して和り，膵管減圧の効果は得られなかっ た。欧米では，このような症例に対して脺全摘あるい は膵亚全摘がよく行われ4)5), 疼痛のコントロールに対 しては，良好な結果が得られている。しかし，わが国 では，疼痛のコントロールのみのために膵全摘あるい は膵亚全摘を適応とすることには否定的である。しか し，このような症例に対して膵頭十二指腸切除術を適 応して好結果を得, 積極的に推奖している報告もあ る6). この効果発現の機序については明らかでないが, 膵頭神経叢第 I 部, 第II 部の切除による効果が大きな 要因と考えられる。一方, 広範囲脺切除術の欠点を補 うため, 膵切除術に加えて，ラ氏島細胞あるいは細胞 片の自家移植を行っている報告もある7). ラ氏島細胞 が生着し機能していることが確認されているが，今後 は，この移植されたラ氏島細胞のみで糖のコントロー ルが維持されらるかどらか，問題が残っている，また 膵切除後 segmental pancreasの自家移植を行い良好 であったとの報告もある゙が，手技的に異所性移植に 伴 う膵管処理の問題, 血行再建後における膵血管内で の血栓形成などの問題点があり，これらの問題点にも かかわらず，自家移植する必要性に問題が残る。この ことに関して，われわれの術式は膵の元の位置のまま で移植出来る状態にまで膵を後腹膜から遊離するもの で,この術式の結果いかんによって, segmental な自家 移植術式の必要性は判然とすると思われる。われわれ の術式の発想もひとえにこの点にある.

一方, 慢性膵资に対し膵頭部のみの神経支配を断つ 膵頭神経叢切除, 腹腔神経節切除, 腹腔神経切除9)など の神経切除が現在までに，膵管非拡張例に限定せずお こなわれているが，これらの術式も当然，膵管非拡張 例に対し適応可能である。しかし，これら神経切除単 独の効果は一時的なことが多く, わが国では膵管ドレ ナージ手術との併用に意義が見出されているにすぎな い. Mallet-Guy ${ }^{10)}$ の腹腔神経切除の長期経過観察例の 報告では，疼痛のコントロールに対する比較的良好な 成績がみられ，再検討する必要があるように思われる。 
われわれは，膵神経叢全切除術を提唱するに当たっ て, 膵管非扗張慢性膵炎の自験例を検討2)し，びまん性 病変を呈する症例は, アルコール性で, 膵機能高度障 害例が多く，いき扣い手術適応は，疼痛除去が主目的 となること, そして, 膵機能高度障害例の膵管径は 5 〜 8 年の経過で, 法とんど変化しないことから, 膵管 ドレナージ手術の適応は長期経過に和いても考克られ にくいことなどの知見を得たまた一方では，膵全摘 または膵亜全摘による過大侵襲と術後の膵機能欠落を 回避すること, 従来の神経切除の効果を脺以外の臓器 に影響を与えずに節後線維を徹底的に切除すること， そして前述したごとく, 膵の segmental な自家移植を 行ら前の状態にし, 合わせて脺自家移植の必要性をも 検討することを思い立った。

膵神経丵全切除術を現在まで 3 例に行った。これら 3 例で, 慢性脺炎に対する治療の成績を問らには術後 3 年 5 力月, 2 年 3 力月, 1 年 7 力月と短い観察期間 であるが, 疼痛のコントロールに関しては, 良好な結 果が得られ，1例はインスリンの投与を受け一時的に 社会復帰したが，2例は完全に社会復帰している。し かし問題点として，1例に，術後一過性の軽度の高つ ミラーゼ血症を伴ら軽度の左季肋部痛を認めたことに より,この疼痛発生の機序として, 膵周囲組織への炎 症の波及によってじゃっ起されたものかどうか問題点 が残っている、しかし、これはららを返せば, 神経叢 全切除を行ってb, 膵での资症発生時, alarm sign しての疼痛は残ることを示しているかもしれない.

本術式の施行に際して，症例によっては炎症所見が ひどい昜合に行えるかどうか，いまだ症例数が少なく 問題点として残っている. 術後, 本術式による合併症 は 1 例のみに術後一過性の下浰を経験している. 吉

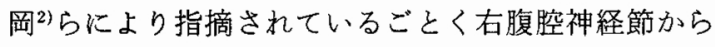
上腸間膜動脈右側に分布する節後線維を妡離すると頑 固な下痳がみられることからこの線維を切除しない ことが肝要である.

最後にアルュール性慢性膵炎患者における術後疼痛 除去後のアルコール摄取の問題がある。本術式を受け た 1 例は術後も飲酒を続けており, 疼痛の発生は認め ていないものの, 慢性膵炎治療に打いては, 外科的治 療以前の問題点が潜んでいるように思われる。慢性膵 炎に対する外科治療を考える時, 慢性膵炎経過の一時 期における激痛を除いてやれば，鎮痛剂による addiction に陥らずに社会復㷌できる症例のみを，今後外科 的治療の対象にしたいと思っている.
おわりに

膵管非拡張慢性膵炎の疼痛コントロールの一術式と して，膵神経叢を完全に切離し，膵を後腹膜腔より完 全に遊離する膵神経叢全切除術を考案し，本術式を 3 例に行い良好な結果を得た。今後さらに症例を重ね, より長期の経過を観察し, 本術式の有用性をさらに検 討していきたい.

\section{文 献}

1) Hiraoka $T$, Watanabe $E$, Katoh $T$ et al: $A$ new surgical approach for control of pain in chronic pancreatitis: Complete denervation of the pancreas. Am J Surg 152:549-551, 1986

2) Yoshioka H, Wakabayashi $T$ : Traitment de la doulur des pancreatitis chroniques par la neurotomei de la tete du pancreas. Une technique nouvelle et ses results. Lyon Chir 53 : $836-845,1957$

3) Hiraoka T, Tashiro S, Watanabe E et al: Surgical treatment of chronic pancreatitis wih. tout pancreatic duct dilation. Edited by Sato $Y$, Yamauchi H: Pancreatitis-Its patho. physiological and clinical aspects. First edition. Tokyo Tokyo Univ. Press Inc, 1985, p419-426

4) Braash JW, Vito L, Nugent FW: Total pancreatectomy of end-stage chronic pancreatitis. Ann Surg 188: 317-322, 1978

5) Frey CF, Child CG, Fry W: Pancreatectomy for chronic pancreatitis. Ann Surg 184 : 403-413, 1976

6）羽生富士夫，鈴木 衛：慢性膵炎の治療法の適応 と限界, 疼痛に対する対策一膵切除術. 胆と膵 $4: 895-901,1983$

7) Sutherland DER, Goets FC, Najarian JS : Pancreas and islet transplantation. Edited by Deut TL, Eckhauser FE, Vinik AI, Turcotte JG: Pancreatic disease, diagnosis, and therapy. First edition. New York, Grune \& Stratton, 1985, p521-537

8) Rossi RL, Braasch JW, Nugent FW et al : Segmental pancreatic autotransplantation for chronic pancreatitis. Am J Surg 145: 437-442, 1983

9) White TT, Lawinski M, Stacher G et al: Treatment of pancreatitis by left splanch. nicectomy and celiac ganglionectomy. Analysis of 146 cases. Am J Surg 112:195-199, 1966

10) Mallet-Guy RA : Late and very late results of resection of the nervous system in the treatment of chronic relapsing pancreatitiis. Am J Surg $145: 234-238,1983$ 